\title{
Fisikokimia, Mikrobiologi dan Organoleptik Sosis Daging Sapi dengan Penambahan Tepung Biji Durian (Durio zibethinus Murr)
}

\author{
Physicochemical, Microbiology and Organoleptic of Beef Sausage with Durian Seed Flour (Durio zibethinus \\ Murr) Addition
}

\author{
A. Apriantini*, D. Afriadi, N. Febriyani, \& I. I. Arief \\ Departemen Ilmu Produksi dan Teknologi Peternakan, Fakultas Peternakan, IPB University, Indonesia \\ Jl. Lingkar Akademik, Kampus IPB Darmaga, 16680 Bogor \\ *Corresponding author: astariapriantini@yahoo.com \\ (Received 12-02-2021; Revised 12-04-2021; Accepted 14-05-2021)
}

\begin{abstract}
Durian seeds are waste products from durian fruit that have not been utilized properly. Durian seed flour contain high starch as well as tapioca flour, therefore, durian seed flour can be combined with tapioca flour as a filler for sausage dough, in order to reduce production costs of sausage products. The aim of this study was to analyze the physicochemical, microbiological and organoleptic properties of beef sausage with the addition of $0 \%, 25 \%$ and $50 \%$ durian seed flour from a maximum $30 \%$ of the flour used in making sausages. The results of physical characteristics showed that the addition of durian seed flour had a significant effect $(\mathrm{P}<0.05)$ on the cohesiveness of sausages and had no significant effect $(\mathrm{P}>0.05)$ on other physical characteristics of sausages. The microbiological assay showed that durian seed flour did not affect the total plate count (TPC) of beef sausages. However, the total plate count of the sausages with the addition of $25 \%$ durian seed flour still met the SNI (Indonesian National Standard) for sausages, instead of sausages with $50 \%$ durian seed flour addition. The results of chemical analysis showed that the addition of durian seed flour had no affect on moisture content, ash content, fat content, protein content, and carbohydrate content of the sausages. The hedonic test values on the parameters of aroma, color, texture and general appearance also showed no significant effect $(P>0.05)$, except for taste parameters. The hedonic quality test value also showed that the addition of durian seed flour had no different effect $(P>0.05)$ on the parameters of aroma, color, texture, and general appearance, but had different effect $(P$ $<0.05)$ on the sausage taste. The addition of durian seed flour produced a distinctive taste which cover the flavor of sausage.
\end{abstract}

Keywords: Beef Sausage, Durian seeds, Durian seed flour

\section{ABSTRAK}

Biji durian merupakan produk limbah dari buah durian yang belum termanfaatkan dengan baik. Tepung biji durian mengandung pati yang sama tinggi dengan tepung tapioka, sehingga tepung biji durian dapat dimanfaatkan sebagai bahan pengisi adonan sosis. Penelitian ini bertujuan untuk menganalisis karakteristik fisikokimia, mikrobiologi dan organoleptik sosis daging sapi yang ditambahkan $0 \%, 25 \%$ dan $50 \%$ tepung biji durian dari maksimal $30 \%$ tepung yang digunakan pada adonan sosis. Pada karakteristik fisik menunjukkan bahwa nilai kekompakan sosis berpengaruh nyata $(\mathrm{P}<\mathbf{0 . 0 5})$ dengan adanya penambahan tepung biji durian, namun untuk karakteristik fisik lainnya tidak menunjukan pengaruh yang nyata $(\mathrm{P}>0.05)$. Pada uji mikrobiologi penambahan tepung biji durian tidak memengaruhi angka lempeng total sosis daging sapi. Namun, hanya sosis dengan tepung biji durian $\mathbf{2 5 \%}$ dan sosis tanpa penambahan tepung biji durian yang menghasilkan angka lempeng total yang masih sesuai dengan SNI 3820:2015. Hasil analisis kimia menunjukkan penambahan tepung biji durian tidak berbeda nyata $(\mathrm{P}>0.05)$ terhadap kadar air, kadar abu, kadar lemak, kadar protein, serta kadar karbohidrat sosis yang dihasilkan. Pada pengujian organoleptik hedonik, parameter rasa menunjukan hasil yang nyata $(\mathrm{P}<0.05)$, namun tidak berpengaruh nyata $(\mathrm{P}>0.05)$ pada aroma, warna, tekstur dan penampilan umum. Nilai uji mutu hedonik menunjukan penambahan tepung biji durian juga berbeda nyata pada parameter rasa sosis $(\mathbf{P}>0.05)$ tetapi tidak berbeda nyata terhadap parameter aroma, warna, tekstur, dan penampilan umum. Penambahan tepung biji durian menghasilkan rasa khas yang dapat menutupi rasa khas bumbu sosis.

Kata kunci : Biji durian, Sosis Sapi, Tepung biji durian 


\section{PENDAHULUAN}

Sosis daging didefinisikan sebagai suatu produk berbahan baku daging yang dihaluskan dengan atau tanpa penambahan pangan lain dan bahan pangan yang diizinkan dan dimasukkan ke dalam selongsong sosis dengan atau tanpa proses pemasakan (BSN 2015). Bahan baku yang digunakan untuk membuat sosis terdiri dari bahan utama yaitu daging dan bahan tambahan seperti bahan pengisi, bahan pengikat, bumbu-bumbu, bahan penyedap, dan bahan makanan lain yang diizinkan (Lawrie 2003). Bahan pengisi merupakan fraksi bukan daging yang ditambahkan dalam pembuatan gel. Bahan pengisi berfungsi sebagai penstabil emulsi, meningkatkan daya ikat air, memperkecil penyusutan, serta menekan biaya (Rosyidi et al. 2008).

Bahan pengisi yang umumnya digunakan dalam pembuatan sosis adalah tepung tapioka. Tepung tapioka memiliki tingkat elastisitas dan kandungan pati yang tinggi (Melia et al. 2010). Tepung biji durian mengandung pati yang sama tinggi dengan tepung tapioka. Tepung tapioka memiliki kadar pati sekitar 90\% (Reputra 2009) dan tepung biji durian mengandung pati sebesar 88.68\% (Malini 2016), sehingga tepung biji durian dapat dimanfaatkan sebagai bahan pengisi adonan sosis.

Produksi durian di Indonesia mencapai 1.14 juta ton dan mengalami peningkatan setiap tahunnya (BPS 2018). Bagian salut buah adalah bagian buah durian yang lebih umum dikonsumsi. Persentase salut buah durian hanya 20\%-35\%. Namun, persentase kulit durian sebesar $60 \%-75 \%$ dan biji durian sekitar 5\%-15\% belum termanfaatkan secara maksimal (Prasetyaningrum 2010). Biji durian hanya menjadi limbah yang sebagian kecilnya dimanfaatkan sebagai pakan ternak dan lebih banyak yang dibuang menjadi sampah. Lebih lanjut, biji durian dapat dimanfaatkan menjadi tepung karena memiliki kadar amilosa berkisar 22.35\% dengan kadar amilopektin berkisar 66.33\% (Malini 2016). Amilosa memberikan sifat keras, sedangkan amilopektin dapat menyebabkan sifat lengket dan membentukan sifat viskoelastis pada produk pangan (Wirawan et al. 2017).

Pemanfaatan tepung dari biji durian untuk bahan pangan telah dibuktikan oleh beberapa penelitian yaitu digunakan untuk penstabil es krim (Sistanto et al. 2017), bahan pengisi nugget (Ageng et al. 2013), roti (Nathanael 2016), dan biskuit (Verawati 2019). Tepung biji durian mengandung kadar pati yang sama tinggi dengan tapung tapioka sehingga diharapkan dapat mengurangi biaya produksi dari sosis dengan mengurangi penggunaan tepung tapioka dan mengkombinasikannya dengan tepung biji durian yang biasa dibuang oleh para pedagang maupun konsumen durian.

Oleh karena itu, penting dilakukan penelitian untuk mencari alternatif lain selain tepung tapioka yang menghasilkan produk sosis yang baik dari segi fisikokimia maupun daya terima oleh konsumen dengan harga yang sangat terjangkau, sehingga dapat meningkatkan konsumsi olahan daging pada masyarakat. Selain itu, pemanfaatan biji durian dapat mengurangi limbah pada lingkungan dan meningkatkan nilai guna dari biji durian. Penelitian ini dilakukan untuk menganalisis karakteristik fisikokimia, mikrobiologi dan daya terima sosis daging sapi yang ditambahkan tepung biji durian.

\section{MATERI DAN METODE}

Daging sapi yang digunakan pada penelitian ini adalah bagian topside. Selain itu, untuk bahan lainnya adalah es batu, lemak sapi, garam, susu skim, bawang putih, lada, jahe, ketumbar, pala, STPP (Sodium tripolyphosphate), selongsong sosis, tepung biji durian dan tepung tapioka. Bahan pengujian yang digunakan seperti larutan buffer $\mathrm{pH} 4$ dan 7 , Plate Count Agar, alkohol, akuades dan Buffer Pepton Water, selenium, brom cresol green methyl red, $\mathrm{HCl}$, heksana, $\mathrm{NaOH}$, larutan $\mathrm{H}_{3} \mathrm{BO}_{3}$

Peralatan yang digunakan untuk membuat sosis yaitu stuffer, tali kasur, termometer, timbangan digital, food processor, kompor dan peralatan dapur. Peralatan untuk analisis terdiri dari texture analyzer, refrigerator, freezer, $\mathrm{pH}$ meter, $\mathrm{a}_{\mathrm{w}}$ meter, sentrifuge, waterbath, vortex mixer, oven, hot plate, autoklaf, tabung reaksi, tabung sentrifus, cawan petri, laminar, mikro pipet, pipet tip, inkubator dan colony counter. v tanur, desikator, cawan, oven, labu kjeldahl, erlenmeyer, ketas saring, ekstraktor soxhlet, dan labu lemak.

Prosedur penelitian ini meliputi pembuatan tepung biji durian, pembuatan sosis, analisis fisikokimia, mikrobiologi dan organoleptik.

\section{Pembuatan Tepung dari Biji Durian}

Tepung biji durian dibuat menggunakan metode penelitian Malini (2016) dengan beberapa modifikasi meliputi: Biji durian dipilih yang keadaannya bagus, setelah itu dicuci hingga bersih, kulit dari biji durian dikupas, lalu biji durian direndam dalam air panas selama 5 menit, setelah itu dilakukan perendaman dalam air kapur 10\% (1 L akuades +10 g kapur sirih) selama 1 jam, biji durian diangkat dari rendaman dan diiris tipis, dijemur selama 3-4 hari hingga kering, dihaluskan dengan penggiling dan diayak.

\section{Pembuatan Sosis}

Pengolahan sosis berdasarkan Arief et al. (2014) dengan modifikasi meliputi perlakuan penambahan tepung dari 30\% total tepung yang digunakan dalam pembuatan sosis dengan konsentrasi sebanyak $0 \%$ tepung biji durian atau $100 \%$ tepung tapioka, $25 \%$ tepung biji durian $+75 \%$ tepung tapioka serta 50\% tepung biji durian $+50 \%$ tepung tapioka (Tabel 1).

Daging sapi bagian topside dibersihkan dan dipotong kecil-kecil. Daging, garam, es batu, lemak dan STPP dimasukkan kedalam food processor lalu digiling selama 5 menit. Setelah itu ditambahkan es batu, susu skim, bawang putih, ketumbar, lada, jahe, pala dan tepung (tepung tapioka dan tepung biji durian dengan perbandingan masing-masing konsentrasi sebesar 1:0; 3:1 dan 1:1) dan digiling selama 90 detik. Adonan dimasukkan ke dalam stuffer untuk pengisian ke dalam selongsong. Sosis dikukus selama 60 menit pada suhu $80-85^{\circ} \mathrm{C}$. 
Tabel 1. Formulasi sosis daging sapi

\begin{tabular}{lcccc}
\hline \multirow{2}{*}{ Jenis Bahan } & $\begin{array}{c}\text { Persentase } \\
(\%)^{*}\end{array}$ & \multicolumn{3}{c}{ Bobot $(\mathrm{g})$} \\
\cline { 3 - 5 } & - & 500.0 & 500.0 & 500.0 \\
\hline Daging sapi & 40.0 & 200.0 & 200.0 & 200.0 \\
Es Batu & 15.0 & 75.0 & 75.0 & 75.0 \\
Lemak & 10.0 & 50.0 & 50.0 & 50.0 \\
Susu Skim & 30.0 & & & \\
Tepung & & 150.0 & 112.5 & 75.0 \\
$\quad$ Tapioka & & 0.0 & 37.5 & 75.0 \\
$\quad$ Biji Durian & 2.5 & 12.5 & 12.5 & 12.5 \\
Bawang putih & 1.4 & 7.0 & 7.0 & 7.0 \\
Garam & 0.7 & 3.5 & 3.5 & 3.5 \\
STPP & 0.7 & 3.5 & 3.5 & 3.5 \\
Lada & 0.5 & 2.5 & 2.5 & 2.5 \\
Pala & 0.5 & 2.5 & 2.5 & 2.5 \\
Jahe & 0.5 & 2.5 & 2.5 & 2.5 \\
Ketumbar & &
\end{tabular}

*Berdasarkan bobot daging yang digunakan; T1: 100\% tepung tapioka (kontrol); T2: $25 \%$ tepung biji durian $+75 \%$ tepung tapioka; T3: $50 \%$ tepung biji durian $+50 \%$ tepung tapioka

\section{Analisis Sifat Fisik}

Nilai pH (AOAC 2005). Nilai $\mathrm{pH}$ diukur menggunakan $\mathrm{pH}$ meter. Alat $\mathrm{pH}$ meter dikalibrasi pada $\mathrm{pH} 4$ dan 7. Sosis ditusuk dengan elektroda dan dibiarkan hingga angka yang tertera pada pengukuran digital tidak berubah.

Nilai aw (AOAC 2005). Pengukuran aw sosis diukur menggunakan aw meter yang telah dikalibrasi. Empat gram sosis dihaluskan kemudian diletakkan di dalam cawan pengukur. Alat dijalankan sampai menunjukkan tanda completed.

Stabilitas Emulsi (Zobra et al. 1993). Sepuluh gram sampel ditimbang dan dimasukkan dalam tabung sentrifuge $15 \mathrm{~mL}$. Sampel dipanaskan dalam waterbath pada suhu $80{ }^{\circ} \mathrm{C}$ selama 30 menit. Selanjutnya sampel disentrifugasi $2.000 \mathrm{rpm}$ selama 15 menit. Volume minyak dan air diukur menggunakan rumus untuk menentukan persentase stabilitas emulsi.

Daya Serap Air (Fardiaz 1992). Satu gram sampel dimasukkan dalam tabung sentrifuge dan ditambahkan 10 $\mathrm{mL}$ akuades kemudian disentrifugasi $3.500 \mathrm{rpm}$ selama 30 menit. Volume supernatan yang berbentuk diukur menggunakan gelas ukur. Selanjutnya daya serap air dihitung secara manual menggunakan rumus.

Profil Tekstur (Samuel dan Peerkhan 2020). Profil tekstur sosis diukur dengan Texture Analyzer Perten Instrument TVT6700. Sampel sosis dengan tinggi $25 \mathrm{~mm}$ diletakkan pada plate texture analyzer. Sampel diukur dengan probe silinder berdiameter $20 \mathrm{~mm}$ dengan tingkat kompresi 50\% serta kecepatan probe $1 \mathrm{~mm} / \mathrm{s}$. Profil tekstur yang diamati berupa kekerasan, kekompakan, gumminess, kekenyalan dan chewiness sosis.

\section{Analisis Sifat Kimia}

Analisis proksimat dilakukan menggunakan metode AOAC (2005) yang telah dimodifikasi. Analisis proksimat yang dilakukan adalah kadar air, kadar abu, kadar protein, kadar lemak dan kadar karbohidrat. Persentase kadar air, kadar abu, kadar protein, dan kadar lemak dihitung menggunakan rumus manual. Kadar karbohidrat sampel dihitung dengan menggunakan metode analisis karbohidrat by difference dari persentase analisis proksimat kadar air, kadar abu, kadar protein, dan kadar lemak.

\section{Analisis Mikrobiologi}

Tahap awal analisis mikrobiologi adalah pengenceran sampel. Larutan pengenceran 10-1 dibuat dengan melarutkan $25 \mathrm{~g}$ sampel sosis dalam $225 \mathrm{~mL}$ buffer pepton water dan dihomogenkan dengan vortex selama 1-2 menit. Sebanyak $1 \mathrm{~mL}$ suspensi dipindahkan ke dalam larutan 9 mL BPW untuk mendapatkan pengenceran 10-2. Pengenceran dilanjutkan hingga pengenceran 10-4. Larutan yang telah diencerkan digunakan untuk pengujian Angka Lempeng Total.

Angka Lempeng Total (BAM 2001). Suspensi $1 \mathrm{~mL}$ dari pengenceran 10-2-10-4 dimasukkan dalam cawan petri secara duplo. Media Plate Count Agar dituang sebanyak 15-20 mL ke dalam cawan dengan suhu $45 \pm 1{ }^{\circ} \mathrm{C}$. Cawan didiamkan sampai agar menjadi padat dan diinkubasi pada suhu $34-36{ }^{\circ} \mathrm{C}$ selama $24-48$ jam dengan posisi terbalik.

\section{Uji Organoleptik}

Uji organoleptik dilakukan pada 40 panelis semi terlatih berdasarkan metode Setyaningsih (2010) yang telah dimodifikasi. Metode yang digunakan untuk uji organoleptik adalah uji hedonik (uji kesukaan) dan uji mutu hedonik yang diujikan terhadap warna, aroma, rasa, tekstur, dan penampilan umum sosis daging sapi. Uji hedonik dan uji mutu hedonik menggunakan skala 1 sampai 5. Skala mutu hedonik yang dilakukan adalah untuk warna, aroma, rasa, tekstur dan penampilan umum.

\section{Analisis Statistik}

Data dianalisis menggunakan analisis sidik ragam (ANOVA) untuk Rancangan Acak Kelompok (RAK) dengan perlakuan penambahan tepung biji durian pada konsentrasi yang berbeda dan dengan tiga kali pengulangan (Steel dan Torrie 1997). Data hasil uji organoleptik dianalisis menggunakan uji non parametrik Kruskal-Wallis. Taraf perlakuan yang berbeda atau sangat berbeda, dilakukan uji beda nilai tengah menggunakan uji Mann Whitney.

\section{HASIL DAN PEMBAHASAN}

\section{Kualitas Fisik Sosis}

\section{Nilai pH}

Penambahan tepung biji durian tidak memengaruhi nilai $\mathrm{pH}$ sosis daging sapi. Hal tersebut karena nilai $\mathrm{pH}$ sosis dipengaruhi oleh nilai $\mathrm{pH}$ daging normal yang sedikit mengalami peningkatan karena faktor pengolahan dan bahan lain yang ditambahkan seperti bumbu, binder dan filler. Soeparno (2005) menyatakan bahwa daging mempunyai $\mathrm{pH}$ ultimat antara 5.3-5.8. Pada penelitian ini, kisaran $\mathrm{pH}$ yang 
dihasilkan diatas $\mathrm{pH}$ ultimat daging tersebut, karena sosis telah mengalami pengolahan dan penambahan bahan lain yang menyebabkan $\mathrm{pH}$ sedikit meningkat walaupun masih berada dalam kisaran $\mathrm{pH}$ ideal untuk sosis masak yaitu 5.66.0 (Tabel 2). Sosis dengan pH 5.6-6.0 memiliki DSA yang lebih tinggi dibandingkan dengan sosis $\mathrm{pH}$ rendah (FAO 2007). Nilai pH yang tinggi akan menghasilkan produk dengan susut masak yang rendah dan tekstur yang lebih lunak (Hui et al. 2001).

Tabel 2. Kualitas fisik sosis daging sapi dengan penambahan tepung biji durian

\begin{tabular}{lccc}
\hline \multirow{2}{*}{$\begin{array}{c}\text { Kualitas } \\
\text { Fisik }\end{array}$} & \multicolumn{3}{c}{ Perlakuan } \\
\cline { 2 - 4 } & $\mathrm{T} 1$ & $\mathrm{~T} 2$ & $\mathrm{~T} 3$ \\
\hline $\mathrm{pH}$ & $6.066 \pm 0.164$ & $6.077 \pm 0.146$ & $6.078 \pm 0.136$ \\
$\mathrm{a}_{\mathrm{w}}$ & $0.873 \pm 0.015$ & $0.877 \pm 0.022$ & $0.875 \pm 0.027$ \\
DSA (\%) & $12.317 \pm 1.877$ & $16.000 \pm 4.775$ & $17.233 \pm 1.472$ \\
Stabilitas & 100 & 100 & 100 \\
emulsi \% & & & \\
\hline
\end{tabular}

T1: tanpa penambahan tepung biji durian atau $100 \%$ tepung tapioka; T2: penambahan $25 \%$ tepung biji durian $+75 \%$ tepung tapioka; T3: penambahan 50\% tepung biji durian $+50 \%$ tepung tapioka; superskrip dengan huruf yang berbeda menunjukkan berbeda nyata $(\mathrm{P}<0.05)$

\section{Nilai $a_{w}$}

Nilai $a_{w}$ merupakan indikator yang berguna dalam memprediksi pertumbuhan bakteri, kapang dan khamir. Penambahan tepung biji durian tidak memengaruhi nilai $a_{w}$ sosis. Nilai $a_{w}$ yang dihasilkan pada sosis yang ditambahkan tepung biji durian yaitu 0.87 (Tabel 2), baik pada penambahan $25 \%$ maupun $50 \%$. Produk dengan nilai $\mathrm{a}_{\mathrm{w}}$ 0.80-0.99 memiliki kadar air yang tinggi dan umumnya dapat ditumbuhi oleh semua jenis mikroorganisme (Buckle et al. 1987).

\section{Daya Serap Air}

Persentase DSA pada sosis yang ditambahkan tepung biji durian lebih besar dibanding kontrol dan meningkat seiring dengan penambahan tepung biji durian pada produk (Tabel 2), hal ini menunjukan bahwa keberadaan tepung biji durian pada sosis dapat meningkatan Daya Serap Air pada produk sosis, DSA merupakan kemampuan dalam menyerap air dan menahannya dalam suatu sistem pangan (Ntau et al. 2017). DSA yang tinggi pada sosis yang ditambahkan tepung biji durian mengakibatkan sedikit air yang hilang selama proses pemasakan sosis, menyebabkan keempukan dan tekstur sosis menjadi lebih baik.

DSA yang lebih tinggi pada produk sosis yang dengan tepung biji durian disebabkan amilopektin tepung biji durian yang lebih rendah yaitu sekitar $66.33 \%$ jika dibandingkan dengan tepung tapioka 82.13\% (Malini 2016). Amilopektin yang tinggi menyebabkan pati cenderung menyerap sedikit air (Saripudin 2006). Sehingga rendahnya amilopektin yang terkandung pada tepung biji durian dapat meningkatkan daya serap air pada produk sosis. Kandungan protein dalam tepung juga memengaruhi kemampuan penyerapan air. Kadar protein yang tinggi pada tepung akan meningkatkan DSA (Potter dan Hotchkiss 1995). Menurut penelitian Malini 2016, kadar protein dalam tepung biji durian lebih tinggi (1.08\%) dibandingkan tepung tapioka $(0.94 \%)$, hal ini merupakan faktor lain yang menyebabkan DSA pada sosis yang ditambahkan tepung biji durian lebih tinggi dibanding kontrol.

\section{Stabilitas Emulsi}

Tabel 2 menunjukkan bahwa nilai stabilitas emulsi sosis daging sapi pada setiap perlakuan adalah $100 \%$. Hal tersebut menunjukkan tidak adanya volume cairan yang dihasilkan. Setiap perlakuan memiliki stabilitas emulsi yang baik sehingga penambahan tepung biji durian tidak memengaruhi stabilitas emulsi sosis. Setiawan (2017) menyatakan bahwa stabilitas emulsi sosis umumnya adalah 90-100\%.

\section{Profil Tekstur Sosis}

\section{Kekerasan}

Kekerasan menunjukkan tekanan yang diberikan terhadap produk sehingga produk tersebut dapat hancur (Moskowitz 1999). Penambahan tepung biji durian tidak berpengaruh nyata terhadap nilai kekerasan sosis (Tabel 3). Kekerasan sosis daging sapi memiliki hubungan dengan kadar lemak tepung yang digunakan. Lemak memberikan sifat empuk pada sosis dan lemak yang semakin rendah akan menghasilkan tekstur sosis yang semakin keras (Kramlich 1971).

Tepung biji durian memiliki kadar lemak yang lebih tinggi (5.40\%) dibandingkan tepung tapioka $(0.34 \%)$ (Malini 2016). Kadar lemak yang tinggi pada tepung memungkinkan terdapatnya jumlah globula lemak yang lebih besar sehingga menghasilkan interaksi protein-

Tabel 3. Profil tekstur sosis daging sapi dengan penambahan tepung biji durian

\begin{tabular}{lccc}
\hline \multicolumn{1}{c}{ Profil tekstur } & \multicolumn{3}{c}{ Perlakuan } \\
\cline { 2 - 4 } & $\mathrm{T} 1$ & $\mathrm{~T} 2$ & $\mathrm{~T} 3$ \\
\hline Kekerasan $\left(\mathrm{Kg} \cdot \mathrm{m} . \mathrm{s}^{-2}\right.$ ) & $20.545 \pm 3.253$ & $20.582 \pm 1.692$ & $17.265 \pm 4.299$ \\
Kekompakan & $0.383 \pm 0.068 \mathrm{a}$ & $0.295 \pm 0.025 \mathrm{ab}$ & $0.257 \pm 0.031 \mathrm{~b}$ \\
Gumminess $\left(\mathrm{Kg} . \mathrm{m} . \mathrm{s}^{-2}\right)$ & $8.033 \pm 2.629$ & $6.066 \pm 0.654$ & $4.486 \pm 1.457$ \\
Kekenyalan & $0.829 \pm 0.054$ & $0.890 \pm 0.099$ & $0.979 \pm 0.139$ \\
Chewiness $\left(\mathrm{Kg} . \mathrm{m} . \mathrm{s}^{-2}\right)$ & $8.591 \pm 2.480$ & $7.060 \pm 0.605$ & $5.833 \pm 1.666$ \\
\hline
\end{tabular}

T1: tanpa penambahan tepung biji durian atau $100 \%$ tepung tapioka; T2: penambahan $25 \%$ tepung biji durian $+75 \%$ tepung tapioka; T3: penambahan $50 \%$ tepung biji durian $+50 \%$ tepung tapioka; superskrip dengan huruf yang berbeda menunjukkan berbeda nyata $(\mathrm{P}<0.05)$ 
protein dan protein-lipid yang lebih rendah. Interaksi yang rendah tersebut menyebabkan penurunan nilai kekerasan pada sosis yang dihasilkan (Yum et al. 2018). Kekerasan sosis akan menurun dengan meningkatnya kadar air. Kadar air yang tinggi kemungkinan disebabkan oleh tepung biji durian yang memiliki sifat DSA yang baik selama proses pembuatan sosis.

\section{Kekompakan}

Kekompakan didefinisikan sejauh mana suatu material dapat berubah bentuk sebelum pecah (Szczesniak 2002). Penambahan tepung biji durian berpengaruh nyata $(\mathrm{P}<0.05)$ terhadap kekompakan sosis daging sapi dimana penambahan tepung biji durian 50\% menghasilkan nilai kekompakan sosis paling rendah (Tabel 3). Kekompakan yang tinggi menunjukkan sosis tersebut lebih sulit pecah sehingga membutuhkan daya kunyah yang lebih besar.

Kekompakan yang tinggi menunjukkan adanya kemampuan matriks pati-protein dalam mempertahankan strukturnya. Sosis daging sapi dengan penambahan tepung biji durian 50\% menjadi kurang kompak karena level gelatinisasi pati pada tepung biji durian yang mengisi ruang kosong matriks protein daging rendah sehingga matriks protein daging tidak dapat mempertahankan dindingnya (Prijambodo et al. 2014).

\section{Gumminess}

Gumminess merupakan energi yang dibutuhkan untuk menghancurkan makanan semi padat menjadi keadaan siap untuk ditelan (Szczesniak 2002). Tabel 3 menunjukkan bahwa penambahan tepung biji durian tidak berpengaruh nyata terhadap gumminess sosis. Gumminess yang rendah menunjukkan bahwa sosis yang dihasilkan semakin mudah dihancurkan saat dikunyah.

Nilai gumminess yang rendah disebabkan oleh rendahnya nilai kekerasan sosis (Tabel 3). Gumminess menunjukkan tren yang sama dengan kekerasan yang dihasilkan karena gumminess dihasilkan melalui perkalian parameter kekerasan dan kekompakan (Hashemi dan Jafarpour 2016).

\section{Kekenyalan}

Kekenyalan secara fisik merupakan kondisi dimana kembalinya bahan yang rusak menjadi kondisi sebelumnya setelah energi yang merusak hilang (Szczesniak 2002). Penambahan tepung biji durian tidak berpengaruh nyata terhadap kekenyalan sosis (Tabel 3). Kekenyalan sosis dipengaruhi oleh DSA sosis. Soeparno (2005) menyatakan bahwa tingginya DSA mengakibatkan sedikit air yang hilang selama proses pemasakan sosis, menyebabkan keempukan dan tekstur sosis menjadi lebih baik.

Tepung biji durian mengandung amilosa sebesar 22.35\% (Malini 2016). Eliasson (2004) menyatakan bahwa kisaran amilosa tepung tapioka 20-27\%. Pati dengan amilosa yang tinggi cenderung mengalami retrogradasi dan menghasilkan gel yang kaku. Tepung biji durian memiliki kadar pati yang lebih tinggi (88.68\%) dibandingkan dengan tepung tapioka (82.41\%) (Malini 2016). Sun dan Yoo (2015) menyatakan bahwa kadar pati yang lebih tinggi akan menghasilkan gel yang lebih lunak dan stabil terhadap sineresis. Gel yang lunak dan stabil akan menyebabkan senyawa polimer hidrofil atau hidrokoloid didispersikan ke dalam air hingga mengembang kemudian terjadi proses hidrasi molekul air melalui pembentukkan ikatan hidrogen dengan molekul air akan terjebak dalam struktur molekul kompleks tersebut sehingga membentuk massa gel yang kenyal (Lieberman et al. 1996).

\section{Chewiness Sosis}

Chewiness merupakan energi yang dibutuhkan untuk mengunyah makanan padat ke kondisi siap untuk ditelan. Tabel 3 menunjukkan penambahan tepung biji durian tidak berpengaruh nyata terhadap nilai chewiness sosis. Chewiness sosis yang semakin rendah menunjukkan daya kunyah yang dibutuhkan juga semakin rendah. Prabpee dan Pongsawatmanit (2011) menyatakan bahwa penambahan tapioka dalam jumlah tinggi pada formula sosis akan meningkatkan kekerasan, gumminess dan chewiness sosis. Penambahan pati tapioka dapat meningkatkan pembentukkan struktur yang diinduksi dengan pemanasan melalui pembengkakan butiran pati yang terdapat dalam matriks gel protein sosis.

\section{Karakteristik Kimia Sosis Daging Sapi}

Karakteristik kimia yang diuji pada penelitian ini adalah kadar air, kadar abu, kadar lemak, kadar protein, dan kadar karbohidrat. Nilai rataan hasil uji sifat kimia sosis daging sapi dengan penambahan tepung biji durian dapat dilihat pada Tabel 4. Hasil analisis ragam menunjukan bahwa penambahan tepung biji durian tidak memberikan pengaruh terhadap karakteristik kimia sosis.

Tabel 4. Sifat kimia sosis daging sapi sosis daging sapi dengan penambahan tepung biji durian

\begin{tabular}{lcccc}
\hline \multicolumn{1}{c}{ Analisis Kimia } & Perlakuan & & $\begin{array}{c}\text { SNI sosis daging } \\
\text { (SNI 3820-2015) } \\
\end{array}$ \\
\cline { 2 - 5 } & $\mathrm{T} 1$ & $\mathrm{~T} 2$ & $\mathrm{~T} 3$ & $\begin{array}{c}(\%) \\
(\%)\end{array}$ \\
\hline Kadar air & $(\%)$ & $61.80 \pm 0.73$ & $62.14 \pm 0.71$ & Maks.67 \\
Kadar abu & $61.64 \pm 0.37$ & $1.79 \pm 0.20$ & $1.90 \pm 0.13$ & Maks.3 \\
Kadar lemak & $1.91 \pm 0.13$ & $4.61 \pm 0.55$ & $5.31 \pm 0.22$ & Maks.25 \\
Kadar protein & $4.40 \pm 1.31$ & $12.53 \pm 0.58$ & $13.14 \pm 1.45$ & Min. 13 \\
Kadar karbohidrat & $12.45 \pm 1.77$ & $19.27 \pm 0.56$ & $17.51 \pm 1.02$ & Maks.8 \\
\hline
\end{tabular}

T1: tanpa penambahan tepung biji durian atau $100 \%$ tepung tapioka; T2: penambahan $25 \%$ tepung biji durian $+75 \%$ tepung tapioka; $\mathrm{T} 3$ : penambahan $50 \%$ tepung biji durian $+50 \%$ tepung tapioka; superskrip dengan huruf yang berbeda menunjukkan berbeda nyata $(\mathrm{P}<0.05)$ 


\section{Kadar Air}

Kandungan air dalam bahan makanan ikut menentukan akseptabilitas, kesegaran dan daya tahan bahan terhadap serangan mikroba (Winarno 2002). Rataan kadar air sosis pada penelitian ini berkisar $61.64 \%-62.14 \%$ dan menunjukan nilai yang tidak berbeda nyata $(\mathrm{P}>0.05)$ (Tabel 4). Kadar air tepung tapioka berkisar $11.10 \%$ (Charoenkul et al. 2011) sedangkan kadar air tepung biji durian yaitu $10.32 \%$ (Malini 2016). Namun, peningkatan persentase tepung biji durian cenderung akan meningkatkan kadar air sosis. Hal ini diduga karena tepung tapioka mengandung amilosa yang tinggi dibandingkan kadar amilosa tepung biji durian. Menurut Malini (2016) kandungan amilosa tepung biji durian sebesar $22.35 \%$, sedangkan tepung tapioka memiliki kadar amilosa sebesar 31.82\% (Reputra 2009). Semakin banyak kadar amilosa yang digunakan maka akan menurunkan kadar air bahan pangan karena semakin banyak air yang diikat dan dilepas oleh pati (Hartika 2009). Kadar air sosis daging sapi pada penelitian ini memenuhi standar mutu sosis daging berdasarkan syarat SNI yaitu maksimal 67\% (BSN 2015).

\section{Kadar Abu}

Kadar abu sosis daging sapi yang ditunjukan pada Tabel 4 berkisar antara 1.79\%-1.91\% dan menunjukkan tidak ada perbedaan nyata antar perlakuan $(\mathrm{P}>0.05)$. Batas maksimum kadar abu sosis daging sapi sesuai SNI adalah 3\% (BSN 2015), dengan demikian kadar abu sosis pada penlitian ini tidak melebihi syarat SNI. Hal ini menunjukan penambahan tepung biji durian tidak berpengaruh terhadap kadar abu sosis. Menurut Amin dan Roslan (2009) kadar abu tepung biji durian sekitar $0.4 \%$ dan kadar abu tepung tapioka berkisar antara 0.1\%-0.4\% (Rahman 2007).

\section{Kadar Lemak}

Rata-rata kadar lemak sosis daging sapi berkisar $4.40 \%-5.31 \%$ dan tidak menunjukan adanya perbedaan kadar lemak antara sosis $(\mathrm{P}>0.05)$ (Tabel 4). Namun, kadar lemak sosis pada setiap penambahan tepung biji durian cenderung mengalami kenaikan. Hal ini diduga karena tepung biji durian memilki kandung lemak yang lebih tinggi yaitu $0.4 \%$ (Amin dan Roslan 2009) dibandingkan dengan tepung tapioka yang memiliki kandungan lemak sebesar 0.34\% (Charoenkul et al. 2011). Kadar lemak sosis pada penelitian ini telah memenuhi syarat SNI yaitu maksimal 25\% (Badan Standardisasi Nasional 2015).

\section{Kadar Protein}

Kadar protein sosis daging sapi berkisar antara $12.45 \%-13.14 \%$ dan hal ini menunjukkan bahwa kadar protein sosis tidak berbeda nyata antar perlakuan $(\mathrm{P}>0.05)$ (Tabel 4). Batas minimum kadar protein sosis daging sapi sesuai SNI adalah 13\%, dengan demikian kadar protein sosis daging sapi P1 (100\% tepung tapioka) dan P2 (75\% tepung tapioka dan $25 \%$ tepung biji durian) kurang dari syarat SNI. Hal ini dipengaruhi oleh rendahnya kadar protein bahan baku selain daging yang digunakan pada adonan (Nurul et al. 2010). Namun, peningkatan persentase tepung biji durian cenderung akan meningkatkan kadar protein sosis. Menurut malini (2016) kadar protein tepung biji durian yaitu 1.08\%, sedangkan kadar protein tepung tapioka $0.59 \%$ (Lekahena 2016). Hal ini menunjukkan bahwa kandungan protein tepung biji durian lebih tinggi dibandingkan tepung tapioka sehingga dapat meningkatkan nilai kandungan protein sosis.

\section{Kadar Karbohidrat}

Nilai rata-rata kadar karbohidrat sosis menunjukan nilai yang tidak berbeda nyata $(\mathrm{P}>0.05)$ dengan rataan berkisar antara $17.51 \%-19.51 \%$ (Tabel 4). Penambahan tepung biji durian cenderung akan menurunkan kadar karbohidrat sosis. Hal ini diduga karena kandungan karbohidrat yang dimiliki tepung tapioka lebih tinggi jika dibandingkan dengan tepung biji durian. Tepung biji durian memiliki kandungan karbohidrat sebesar 82.04\% (Malini 2016) sedangkan tepung tapioka memiliki karbohidrat sebesar 87.95\% (Charoenkul et al. 2011).

\section{Kualitas Mikrobiologi Sosis}

Penambahan tepung biji durian tidak memengaruhi angka lempeng total sosis daging sapi karena tepung biji durian tidak mengandung zat antibakteri. Tabel 5 menunjukkan bahwa penambahan tepung biji durian 50\% menghasilkan angka lempeng total $(5.024 \pm 0.439$ log cfu $\mathrm{g}^{-1}$ ) yang berada diatas SNI 3820:2015 tentang sosis daging yaitu maksimal $5 \log \mathrm{cfu} \mathrm{g}^{-1}$. Namun, hanya penambahan tepung biji durian $25 \%$ yang menghasilkan angka lempeng total yang masih sesuai dengan SNI 3820:2015.

Bahan baku dalam pembuatan sosis dapat memengaruhi angka lempeng total sosis. Populasi mikroba yang tinggi kemungkinan disebabkan oleh bakteri asam laktat alami pada daging dan bakteri pencemar lain yang mengontaminasi daging selama proses pemotongan ternak di RPH, distribusi dan penjualan daging di pasar (Syudhly 2010). Tepung biji durian memiliki angka lempeng total sebesar 5.079 log cfu g $\mathrm{g}^{-1}$ (Malini 2016).

Angka lempeng total sosis juga dapat dipengaruhi oleh nilai pHnya. Nilai $\mathrm{pH}$ sosis yang dihasilkan berkisar 6.066-6.078. Nilai $\mathrm{pH}$ medium sangat memengaruhi jenis mikroba yang tumbuh.

Tabel 5. Angka lempeng total sosis daging sapi dengan penambahan tepung biji durian

\begin{tabular}{cc}
\hline Pelakuan & Angka Lempeng Total $\left(\right.$ Log cfu g $\left.{ }^{-1}\right)$ \\
\hline T1 & $4.238 \pm 0.092$ \\
T2 & $4.685 \pm 0.361$ \\
T3 & $5.024 \pm 0.439$ \\
\hline
\end{tabular}

T1: tanpa penambahan tepung biji durian atau $100 \%$ tepung tapioka; T2: penambahan $25 \%$ tepung biji durian $+75 \%$ tepung tapioka; T3: penambahan $50 \%$ tepung biji durian $+50 \%$ tepung tapioka

\section{Organoleptik Sosis Daging Sapi}

Pengujian sensori atau pengujian dengan indera atau dikenal dengan pengujian ini digunakan untuk mengetahui daya terima dan menilai mutu suatu produk (Soekarto 1990). Uji mutu hedonik menunjukkan kesan yang lebih spesifik daripada sekedar kesan suka atau tidak suka, sedangkan uji hedonik moerupakan salah satu jenis uji penerimaan (Setyaningsih et al. 2010). Uji hedonik dan mutu hedonik 
Tabel 6. Uji hedonik dan uji mutu hedonik sosis daging sapi

\begin{tabular}{lccc}
\hline & Parameter & Perlakuan & T3 \\
\cline { 2 - 4 } & T1 & & \\
\hline Hedonik & $3.65 \pm 0.86$ & $3.45 \pm 0.78$ & $3.55 \pm 0.85$ \\
Aroma & $3.38 \pm 0.74$ & $3.55 \pm 0.78$ & $3.50 \pm 1.00$ \\
Warna & $3.68 \pm 0.76 \mathrm{a}$ & $3.55 \pm 0.75 \mathrm{a}$ & $3.05 \pm 0.90 \mathrm{~b}$ \\
Rasa & $3.20 \pm 0.79$ & $3.13 \pm 0.94$ & $3.05 \pm 1.01$ \\
Tekstur & $3.65 \pm 0.66$ & $3.58 \pm 0.59$ & $3.45 \pm 0.78$ \\
Penampilan umum & $3.51 \pm 0.76$ & $3.45 \pm 0.77$ & $3.32 \pm 0.91$ \\
\hline Rata-rata & & & $2.33 \pm 0.98$ \\
\hline Mutu hedonic & $2.18 \pm 0.93$ & $2.13 \pm 0.85$ & $3.25 \pm 0.78$ \\
Aroma & $3.43 \pm 0.87$ & $3.55 \pm 0.64$ & $2.88 \pm 1.07 \mathrm{~b}$ \\
Warna & $3.68 \pm 0.80 \mathrm{a}$ & $3.40 \pm 0.84 \mathrm{a}$ & $2.90 \pm 0.90$ \\
Rasa & $3.23 \pm 0.83$ & $3.05 \pm 0.71$ & $3.23 \pm 0.89$ \\
Tekstur & $3.65 \pm 0.62$ & $3.33 \pm 0.86$ & $2.92 \pm 0.94$ \\
Penampilan umum & $3.23 \pm 0.81$ & $3.09 \pm 0.78$ & \\
\hline Rata-rata & & & \\
\hline
\end{tabular}

P1: T1: tanpa penambahan tepung biji durian atau $100 \%$ tepung tapioka; $\mathrm{T} 2$ : penambahan $25 \%$ tepung biji durian $+75 \%$ tepung tapioka; T3: penambahan $50 \%$ tepung biji durian $+50 \%$ tepung tapioka; superskrip dengan huruf yang berbeda menunjukkan berbeda nyata $(\mathrm{P}<0.05)$. Skala uji hedonik yang digunakan yaitu 1 (sangat tidak suka), 2 (tidak suka), 3 (agak suka), 4 (suka), 5 (sangat suka). Skala mutu hedonik yang digunakan yaitu Aroma: 5 (sangat beraroma durian); 4 (beraroma durian); 3 (sedikit beraroma durian); 2 (tidak beraroma durian); 1 (sangat tidak beraroma durian), warna: 5 (coklat tua); 4 (coklat); 3 (coklat muda); 2 (coklat kemerahan); 1 (merah), rasa: 5 (sangat terasa bumbu khas sosis); 4 (terasa bumbu khas sosis); 3 (sedikit terasa bumbu khas sosis); 2 (tidak terasa bumbu khas sosis); 1 (sangat tidak terasa bumbu khas sosis), tekstur: 5 (sangat kenyal); 4 (kenyal); 3 (agak kenyal); 2 (tidak kenyal); 1 (sangat tidak kenyal), penampilan umum: 5 (sangat menarik); 4 (menarik); 3 (agak menarik); 2 (tidak menarik); 1 (sangat tidak menarik).

pada penelitian ini melibatkan 40 orang panelis semi terlatih. Hasil rataan pengujian organoleptik dapat dilihat pada Tabel 6 .

\section{Aroma}

Nilai rataan uji hedonik terhadap aroma sosis pada Tabel 6 menunjukan hasil yang tidak berbeda nyata $(\mathrm{P}>0.05)$. Panelis agak menyukai semua sosis, baik tanpa penambahan tepung biji durian maupun yang ditambahkan tepung biji durian. Aroma sosis kontrol cenderung lebih disukai oleh panelis dibandingkan dengan sosis yang ditambahkan tepung biji durian. Nilai rataan uji mutu hedonik terhadap aroma sosis menunjukan tidak ada perbedaan nyata pada aroma sosis $(\mathrm{P}>0.05)$. Panelis menilai aroma sosis yang dihasilkan tidak beraroma durian. Hal ini diduga karena aroma pada tepung biji durian yang tidak menyengat serta tertutup aroma bumbu yang ditambahkan. Menurut Winarno (2002) salah satu hal yang mempengaruhi aroma produk olahan daging adalah bahan-bahan yang ditambahkan selama pembuatan produk. Aroma yang ditimbulkan pada sosis berasal dari senyawa-senyawa volatil yang terdapat pada daging sapi dan pencampuran bumbu. Bumbu dapat memberikan citarasa dan mampu meningkatkan aroma sosis (Zuriyati 2011).

\section{Warna}

Nilai rata-rata uji hedonik pada Tabel 6 menujukan tidak ada perbedaan nyata $(\mathrm{P}>0.05)$ tingkat kesukaan panelis terhadap warna sosis. Namun, warna sosis T2 (75\% tepung tapioka dan $25 \%$ tepung biji durian) cenderung lebih disukai oleh panelis. Nilai rataan uji mutu hedonik terhadap warna juga memperoleh hasil yang tidak berbeda nyata $(\mathrm{P}>0.05)$. Pada umumnya tepung biji durian berwarna putih kekuningan sedangkan tepung tapioka berwana putih. Panelis menilai bahwa warna yang dihasilkan sosis adalah coklat muda. Sehingga warna dari tepung durian tidak mempengaruhi warna dari produk sosis. Warna sosis diantaranya dipengaruhi oleh kandungan mioglobin daging. Mioglobin merupakan pigmen dalam otot daging terdiri dari protein. Mioglobin dapat teroksidasi pada suhu $80-85^{\circ} \mathrm{C}$ akan membentuk metmioglobin yang menyebabkan warna coklat (Soeparno 2005).

\section{Rasa}

Tingkat kesukaan panelis terhadap rasa sosis pada penelitian ini menunjukkan hasil yang berbeda nyata $(\mathrm{P}<0.05)$ (Tabel 6). Rasa sosis daging kontrol T1 $(100 \%$ tepung tapioka) dengan T2 (75\% tepung tapioka dan 25\% tepung biji durian) tidak berbeda nyata, namun berbeda nyata dengan rasa sosis daging T3 (50\% tepung tapioka dan $50 \%$ tepung biji durian). Penambahan tepung biji durian cenderung menurunkan tingkat kesukaan panelis terhadap rasa sosis. Sosis kontrol tanpa penambahan tepung biji durian (T1) cenderung lebih disukai panelis dibandingkan dengan sosis dengan penambahan tepung biji durian baik T2 dan T3. Hal ini dapat disebabkan karena sosis kontrok T1 (100\% tepung tapioka) memiliki rasa khas bumbu sosis yang lebih kuat dibandingkan dengan sosis lainya. Adanya rasa durian pada sosis menurunkan kesukaan panelis terhadap sosis. 
Rataan uji mutu hedonik menunjukan adanya perbedaan nyata $(\mathrm{P}<0.05)$ pada rasa sosis. Rasa sosis daging T1 (100\% tepung tapioka) tidak berbeda dengan sosis T2 (75\% tepung tapioka dan $25 \%$ tepung biji durian), namun berbeda dengan sosis T3 (50\% tepung tapioka dan $50 \%$ tepung biji durian). Sosis T1 dan T2 masih memiliki rasa bumbu khas sosis, sedangkan sosis T3 sudah muncul rasa durian pada produk sosis, sehingga mempengaruhi rasa khas sosis. Penambahan tepung biji durian mulai pada konsentrasi 50\% memunculkan rasa khas biji durian yang dapat mempengaruhi rasa khas bumbu. Prasetyo et al. (2018) menyatakan tepung biji durian memiliki rasa getir akibat lendir yang belum sepenuhnya hilang pada proses pengolahan biji durian menjadi tepung, hal ini mempengaruhi rasa maupun aroma pada produk sosis yang dibuat.

\section{Tekstur}

Nilai rataan uji hedonik terhadap tekstur sosis pada Tabel 6 menunjukan hasil yang tidak berbeda nyata $(\mathrm{P}>0.05)$. Penilaian pada tekstur sosis T1, T2 dan T3 yaitu agak disukai oleh panelis. Rataan mutu hedonik terhadap tekstur juga menunjukan hasil yang tidak berbeda nyata $(\mathrm{P}>0.05)$. Sosis T3 (50\% tepung tapioka dan 50\% tepung biji durian) dinilai memiliki tekstur yang tidak kenyal atau lunak. Hal ini diduga karena tepung biji durian yang berfungsi sebagai bahan tambahan memiliki kadar amilopektin yang lebih rendah yaitu 66.33\% (Malini 2016) dibandingkan dengan kadar amilopektin tepung tapioka sebesar 68.18\% (Reputra 2009). Budi (2014) menyatakan amilopektin menyebabkan pati mengalami gelatinisasi, pengentalan serta strukur granula yang lebih kompak, sehingga dapat menghasilkan sosis yang lebih kenyal.

\section{Penampilan Umum}

Penampilan umum merupakan pertimbangan terakhir konsumen dalam menerima suatu produk baru. Rataan nilai uji hedonik penampilan umum menunjukan hasil yang tidak berbeda nyata $(\mathrm{P}>0.05)$ dan menunjukan panelis agak suka terhadap penampilan umum ketiga sampel sosis. Namun penampilan umum sosis kontrol T1 (100\% tepung tapioka) cenderung lebih disukai dibandingkan sosis dengan penambahan tepung biji durian. Selain itu semakin tinggi persentase tepung biji durian, semakin rendah penilaian panelis terhadap penampilan umum sosis. Rataan uji mutu hedonik untuk sosis menunjukan hasil yang tidak berbeda nyata $(\mathrm{P}>0.05)$ dan menunjukan ketiga perlakuan sosis yang dihasilkan agak menarik, walaupun nilai untuk sosis kontrol T1 lebih tinggi dibandingkan sosis dengan penambahan tepung biji durian dan peningkatan persentase tepung biji durian menurunkan penilaian panelis terhadap penampilan umum uji mutu hedonik.

\section{KESIMPULAN}

Kombinasi tepung biji durian $25 \%$ dan tepung tapioka $75 \%$ dapat digunakan sebagai bahan pengisi pada pembuatan sosis daging sapi. Penggunaan tepung biji durian mempengaruhi tingkat kekompakan sosis daging sapi. Pada uji mikrobiologi penambahan tepung biji durian tidak mempengaruhi angka lempeng total sosis daging sapi. Namun, angka lempeng total yang masih sesuai dengan SNI 3820:2015 adalah hanya pada sampel sosis tanpa penambahan tepung biji durian dan sosis dengan penambahan tepung biji durian 25\%. Penggunaan tepung biji durian sebagai pengganti tepung tapioka pada produk sosis daging sapi pada taraf $50 \%$ tidak berpengaruh terhadap karakteristik kimia dan organoleptik sosis, namun memberikan pengaruh yang berbeda terhadap nilai hedonik dan mutu hednonik rasa sosis daging sapi. Penambahan tepung biji durian dapat menurunkan tingkat kesukaan panelis terhadap rasa sosis. Penambahan tepung biji durian menghasilkan rasa khas yang dapat menutupi rasa khas bumbu sosis.

\section{DAFTAR PUSTAKA}

AOAC (Association of Official Analitycal Chemistry). 2005. Official Method of Analysis. $18^{\text {th }} \mathrm{Ed}$. Maryland (US): AOAC International.

Ageng, M. P., R. Djalal, \& S. W. Eny. 2013. Pengaruh penambahan pati biji durian terhadap kualitas kimia dan organoleptik nugget ayam. Jurnal Ilmu-Ilmu Peternakan. 23(3):17-26.

Amin, A. M., \& A. Roslan. 2009. Proximate composition and pasting properties of durian (Durio zibethinus) seed flour. Int. J. Postharvest Technology and Innovation. 1(4):367-375.

Arief, I. I., T. Suryati, D. N. Afiyah, \& D. P. Wardhani. 2014. Physicochemical and organoleptic of beef sausages with teak leaf extrack (Itectona grandis) addition as preservative and natural dye. Internasional Food Recearch Journal. 21(5):2033-2042.

BPS (Badan Pusat Statistik). 2018. Statistik Tanaman Buah-buahan dan Sayuran Tahunan Indonesia. Jakarta (ID): Badan Pusat Statistik.

BSN (Badan Standardisasi Nasional). 2015. SNI 38202015. Sosis Daging. Jakarta (ID): Dewan Standarisasi Nasional.

Buckle, K. A., R. A. Edwards, G. H. Fleet, \& M. Wotton. 1987. Ilmu Pangan. Purnomo H, Adiono, penerjemah. Jakarta (ID). UI Pr.

Charoenkul, N., U. Dudsadee, P. Worayudh, \& T. Yasuhito. 2011. Physicochemical characteristics of starches and flours from cassava varieties having different cooked root textures. LWT-Food Science and Technology. 44(8):1774-1781.

Eliasson, A. C. 2004. Starch in Food: Structure, Function and Applications. Florida (US): CRC Press.

FAO (Food and Agriculture Organization). 2007. Meat Proccessing Technology for Small to Medium Scale Producers. Bangkok (TH): Food and Agriculture Organization. 
Fardiaz, S. 1992. Mikrobiologi Pangan I. Jakarta (ID): Gramedia Pustaka Utama.

Feng, C., D. Sun, J. F. G. Martin, \& Z. Zhang. 2013. Effects of different cooling methods on shelf-life of cooked jumbo plain sausages. Food Sci Techn. 54:426433.

Hartika, W. 2009. Kajian sifat fisik dan kimia tepung biji nangka (Artocarpus heterophyllus Lamk) dan aplikasinya dalam pembuatan roti manis [skripsi]. Padang (ID): Universitas Andalas.

Hashemi, A., \& A. Jafarpour. 2016. Rheological and microstructural properties of beef sausage batter formulated with fish fillet mince. Journal of Food Science Technology. 53(1):601-610.

Hui, Y. H., W. K. Nip, R. Rogers, \& O. A. Young. 2001. Meat Science and Applications. New York (US): Marcel Dekker Inc.

Khotimah, K., \& E. S. Hartatie. 2013. Kualitas fisika kimia sosis ayam dengan penggunaan labu merah (Cucurbita moschata) sebagai alternatif pengganti pewarna dan antioksidan. Jurnal Ilmu Ternak. 13(1):35-38.

Kramlich, R. V. 1973. Sausage Product. 2nd Edition. San Fransisco (US): W.H. Freeman and Company.

Lawrie, R. A. 2003. Ilmu Daging. Ed ke-5. Parakkasi A, penerjemah. Jakarta (ID): UI Pr. Terjemahan dari: Meat Science.

Lekahena, V. N. J. 2016. Pengaruh penambahan konsentrat tepung tapioka terhadap komposisi gizi dan evaluasi sensori nugget daging merah ikan madidihang. Jurnal Imlimiah Agribisnis dan Perikanan. 9(1):1-8.

Lieberman, H. A., L. Lachman, \& J. L. Kanig. 1996. Teori dan Praktik Farmasi Industri. Edisi Ke-3. Jakarta (ID): UI Pr.

Luna, P., H. Herawati, S. Widowati, \& A. B. Prianto. 2015. Pengaruh kandungan amilosa terhadap karakteristik fisik dan organoleptik nasi instan. Jurnal Penelitian Pascapanen Pertanian. 12(1):1-10.

Malini, D. R. 2016. Pemanfaatan tepung biji durian sebagai bahan pengisi bakso daging sapi [tesis]. Bogor (ID): Institut Pertanian Bogor

Mattjik, A. A., \& M. Sumertajaya. 2000. Perancangan Percobaan dengan Aplikasi SAS dan Minitab. Bogor (ID): IPB Pr.

Melia, S., I. Juliyarsi, \& A. Rosya. 2010. Peningkatan kualitas bakso ayam dengan penambahan tepung talas sebagai subtitusi tepung tapioka. Jurnal Peternakan. $7(2): 62-69$

Moskowitz, H. R. 1999. Food Texture: Instrumental and Sensory Measurement. New York (US): Marcel Dekker Inc.

Nathanael, R. S., R. Efendi, \& Rahmayuni. 2016. Penambahan tepung biji durian (durio zibethinus murr) dalam pembuatan roti tawar. JOM Faperta. 3(2):1-15.

Nurul, H., T. L. J. Alistair, H. W. Lim, \& I. Noryati. 2010. Quality characteristics of Malaysian commercial beef frankfurters. Internasional Food Research Journal. 17:469-476.

Ntau, L., M. F. Sumual, \& J. R. Assa. 2017. Pengaruh fermentasi Lactobacillus casei terhadap sifat fisik tepung jagung manis (Zea mays saccharata Sturt). Jurnal Ilmu dan Teknologi Pangan. 5(2):11-19.

Potter, N. N., \& J. H. Hotchkiss. 1995. Food Science. New Delhi (IN): CBS Publishers \& Distributors.

Prabpree, R., \& R. Pongsawatmanit. 2011. Effect of tapioca starch concentration on quality and freeze-thaw stability of fish sausage. Kasetsart Journal (National Science). 45(2):314-324.

Prasetyaningrum. 2010. Mekanisasi proses olahan biji durian menjadi produk pangan yang kompetitif. Jurnal Riptek. 4(2):47-52.

Prasetyo, L., A. Akhyar, \& Z. Yelmira. 2018. Pemanfaatan tepung biji durian dan tepung kacang hijau dalam pembuatan flakes. JOM Faperta. 5(1): 1-12.

Prijambodo, O. M., C. Y. Trisnawati, \& A. M. Sutedja. 2014. Karakteristik fisikokimia dan organoleptik sosis ayam dengan proporsi kacang merah kukus dan minyak kelapa sawit. Jurnal Teknologi Pangan dan Gizi. 13(1):6-11.

Ray, B. 2004. Fundamental Food Microbiology. 3rd Edition. Florida (US): CRC Pr.

Rahman, A. D. 2007. Mempelajari karakteristik kimia dan fisil tepung tapioka dan mocal (modified cassava flour) sebagai penyalut kacang pada produk kacang salut [skripsi]. Bogor (ID): Institut Pertanian Bogor.

Reputra, J. 2009. Karakterisasi tapioka dan penentuan formulasi premix sebagai bahan penyalut untuk produk fried snack [skripsi]. Bogor (ID): Institut Pertanian Bogor

Rosyidi, D., A. S. Widati, \& J. Prakoso. 2008. Pengaruh penggunaan rumput laut terhadap kualitas fisik dan organoleptik chicken nugget. Jurnal Ilmu dan Teknologi Hasil Ternak. 3(10):43-51.

Saripudin, U. 2006. Rekayasa proses tepung sagu (metroxylon sp) dan beberapa karakternya [skripsi]. Bogor (ID): Institut Pertanian Bogor.

Samuel, K. S., \& N. Peerkham. 2020. Pearl millet protein bar: nutritional, organoleptic, textural characteristic, and in vitro protein and starch digestibility. Journal Food Science Technol. 1(1):1-7.

Setiawan, D. 2017. Sifat fisik mikrobiologi dan mikrobiologi sosis daging sapi dengan penambahan pasta buah merah pada penyimpanan suhu ruang [skripsi]. Bogor (ID): Institut Pertanian Bogor.

Setyaningsih, D., A. Apriyantono, \& M. P. Sari. 2010. Sensory Analysis for Food and Agro. Bogor (ID): IPB Pr.

Sistanto, E. Sulistyowati, \& Yuwana. 2017. Pemanfaatan limbah biji durian (durio zibethinus murr) sebagai bahan penstabil es krim susu sapi perah. Jurnal Sain Peternakan Indonesia. 12(1):9-23.

Soekarto. 1990. Penilaian Organoleptik untuk Industri Pangan dan Hasil Pertanian. Jakarta (ID): Bhatara Aksara.

Soeparno. 2005. Ilmu dan Teknologi daging. Yogyakarta (ID): UGM Pr.

Suhardjo. 2003. Berbagai Cara Pendidikan Gizi. Jakarta (ID): Bumi Aksara

Sun, D., \& B. Yoo. 2015. Effect tapioca starch addition on 
rheological, thermal and gelling properties of the rice starch. LWT - Food Science and Technology. 64:205211.

Syudhly, A. M. S. 2010. Sifat mikrobiologi sosis frankfurter dengan angkak dan rosela sebagai bahan tambahan alami subtitusi nitrit [skripsi]. Bogor (ID): Institut Pertanian Bogor.

Szczesniak, A. S. 2002. Texture is asensory property. Food Quality and Preference. 13:215-225.

Verawati, B., \& N. Yanto. 2019. Substitusi tepung terigu dengan tepung biji durian pada biskuit sebagai makanan tambahan balita underweight. Media Gizi Indonesia. 14(1):106-114

Winarno, F. G. 2002. Kimia Pangan dan Gizi. Jakarta (ID): PT Gramedia Pustaka Utama.

Wirawan, Y., D. Rosyidii, \& E. S. Widyastuti. 2017. Pengaruh penambahan pati biji durian (duriozibethinusmurr) terhadap kualitas kimia dan organoleptik bakso ayam. Jurnal Ilmu dan Teknologi Hasil Ternak. 12(1):39-46.
Yum, H. W., J. K. Seo, J. Y. Jeong, G. D. Kim, M. S. Rahman, \& H.S. Yang. 2018. The quality improvement of emulsion-type pork sausages formulated by substituting pork back fat with rice bran oil. Korean Journal of Food Science. 38(1):123-134.

Zobra, O., H. Y. Gokalp, H. Yetim, \& H. W. Ockerman. 1993. Model system evaluations of the effects of different levels of $\mathrm{K} 2 \mathrm{HPO} 4, \mathrm{NaCl}$ and oil temperature on emulsion stability and viscosity of fresh and frozen Turkish style meat emulsion. Meat Sci. 34(2):145-161.

Zurriyati, Y. 2011. Palatabilitas bakso dan sosis sapi asal daging segar, daging beku dan produk komersial. Jurnal Peternakan. 8(2):49 -57. 